\title{
Survey of Nematode Destroying Fungi from Selected Vegetable Growing Areas in Kenya
}

\author{
Wachira P. M. ${ }^{1, ~}$, Muindi J. N. ${ }^{2}$, Okoth S. A. ${ }^{1}$ \\ ${ }^{1}$ School of biological Sciences, University of Nairobi, Nairobi, Kenya \\ ${ }^{2}$ Faculty of Science, Department of Biology, Catholic University of East Africa, Nairobi, Kenya
}

Email address:

pwachira@uonbi.ac.ke (Wachira P. M.)

\section{To cite this article:}

Wachira P. M., Muindi J. N., Okoth S. A.. Survey of Nematode Destroying Fungi from Selected Vegetable Growing Areas in Kenya. Agriculture, Forestry and Fisheries. Vol. 4, No. 4, 2015, pp. 159-164. doi: 10.11648/j.aff.20150404.12

\begin{abstract}
Plant parasitic nematodes cause up-to 5\% yield losses to a wide range of economic crops. In Kenya vegetables yield loss attributed to plant parasitic nematodes is estimated to $80 \%$. Over the years, nematode control has heavily on the use of chemical nematicides which unfortunately leads to biological magnification and elimination of the beneficial microorganisms in the soil. This has triggered a growing interest in search of alternate management strategies. The objective of this study was, therefore, to document nematode destroying fungi in selected major vegetable growing areas in Kenya as a step towards developing self-sustaining system for management of plant parasitic nematodes. Soil samples were collected from five vegetable production zones in Kenya which were Kinare, Kabete, Athi-river, Machakos and Kibwezi and transported to the laboratory for extraction of the nematode destroying fungi. Soil sprinkle technique as described by Jaffee et al., (1996) was used to isolate the fungi from the soil while identification was done using identification keys described by Delgado et al.,(2001). From the study a total of 171 fungi isolates were identified as nematode destroying fungi. The highest population was recorded at Kabete area recording 33.9\% of the total record, followed by Machakos, Kibwezi, Athi-river and the least in Kin are with 24.6, 22.2, 11.7 and 7. 6\% of the total population in that order. Arthrobotrys was the most frequent genera with a mean occurrence of 7.3 followed by Monacrosporium with 6 and Stylophage with 5.2. A.dactyloides was significantly $(\mathrm{P}=0.002)$ affected by the agro-ecological zones with the highest occurrence being recorded in Kabete and the least in Athiriver. The highest diversity index and species richness of nematode destroying fungi was recorded in Kibwezi while the least was recorded in Athi-river. The genera Arthrobotrys had the highest number of trapped nematodes with a total population of 57, followed by Monacrosporium and least was Stylopage with 45 and 36 respectively, within a period of 104 hours. From the study, it is evident that agricultural practices affect the occurrence and diversity of nematode destroying fungi and Arthrobotrys can be developed as a bio-control agent for management of plant parasitic nematodes.
\end{abstract}

Keywords: Arthrobotrys, Biological Control, Plant Parasitic Nematodes

\section{Introduction}

Horticultural crops both for local consumption and export are important in Kenya. One-tenth of vegetables in Kenya are grown for export. They are recognized for their health and nutritional benefits; provide cash income and employment for close-to two million people in Kenya (Dobson, et al., 2004). Production of vegetables in Kenya, especially for the expanding domestic market, is still limited by major pest and disease problems (Dobson, et al., 2004). Plant parasitic nematodes have been identified as a major production constrains affecting vegetable production, reducing its yield quality and quantity (Nchore et al., 2010). They are responsible to up to $80 \%$, on vegetables production
(Kaskavalci, 2007).Vegetable production in Kenya is characterized by high chemical inputs for pest and soil fertility management (Mutsotso et al., 2005). These practices have been associated with increases in soil born disease and decline in beneficial soil microorganisms (Wachira et al, 2008). Specifically vegetable damage by Root-Knot nematodes in Kenya has been reported with infected plants being rendered unacceptable for international markets (Nchore et al., 2010). The root knot nematodes increase wounding of the root system providing points of ingress for the pathogen. They may also modify the tissue becoming more suitable for bacteria colonization (Hayward, 1991). Globally it is estimated that US\$500 million is spent on rootknot nematode control (Keren-Zur et al., 2000, Pinkerton et 
al. 2000.) where range of strategies are used to control them. These include the use of nematicides, organic manure amendment and resistant cultivars. Overall, although nematicides are effective in managing root-knot nematodes and other plant parasitic nematodes, they are expensive and environmental pollutants when not applied at the right time, in the right way and in the right dosage increasing the cost of production and reducing the profit for the farmers (Republic of Kenya, Taita District Development Strategies 20022006).Their use is also curtailed by their threat to groundwater, soil biodiversity as well as long waiting periods between use, harvesting and marketing of crops (Bridge, 1996).

Alternatively, soil beneficial microorganisms could be used to reduce the effect of plant parasitic nematodes hence, reducing the application of chemical nematicides to the soil. The beneficial microorganisms are non-polluting and thus environmentally safe and acceptable. Usually they are species specific to target pest and therefore no chances affecting non target species unlike the chemicals which are broad spectra in action. Nematode destroying fungi are such beneficial microorganism that can be used to control plant parasitic nematodes. They are micro fungi that are natural enemies of nematodes. They naturally capture, kill and digest nematodes in the soil (Rodrigues et al., 2001, NordbringHertz et al., 2002). They comprise three main groups of fungi, the nematode trapping, the endoparasitic fungi and the eggand cyst-parasitic fungi (Nordbring-Hertz et al., 2002; Masoomeh, et al., 2004,). After trapping the nematodes, they penetrate the cuticle and invade the entire body cavity and then digest them completely. This group of fungi has drawn much attention due to their potential for development as biological control agents of plant parasitic nematodes (Jansson and Persson, 2000; Sanyal, 2000; Masoomeh, et al., 2004). About $70 \%$ of fungi genera and 160 species are associated with nematodes but only a few of them can be used as biological control agents of nematodes (Elshafie et.al. 2006). This study was therefore aimed at documenting the occurrence and diversity of nematode destroying fungi and testing their as bio-control against plant parasitic nematodes.

\section{Materials and Methods}

Soil samples were collected from five different vegetable growing areas in Kenya. These areas were Kinare, Kabete, Athi-river Machakosand Kibwezi in the order of altitude and temperature. Kinare was a high altitude area and the coldest among the zones and Kibwezi being the lowest and hottest. The vegetable gardens in each zone were mainly dominated by spinach, kales, tomatoes, cabbage and pepper among other vegetables. From each of the study areas five farms under intensive vegetable production were randomly selected for this study. From each of the farm, five different vegetable gardens were sampled. From each vegetable garden, five soil samples were collected and mixed in a bucket to make one composite sample. One kilogram of soil was then re-sampled from the composite sample in the bucket, put in plastic bags, labeled and placed in a cool box. Soil sampling was done using a soil auger which was sterilized using ethanol after every sampling point to avoid cross contamination. All the samples were later transported to the laboratory for isolation of nematode destroying fungi.

Isolation of nematodes destroying fungi was done using the soil sprinkle technique as described by Jaffee et al., 1996 where tap water agar (TWA) was prepared by dissolving $20 \mathrm{~g}$ agar in one liter of tap water. The medium was autoclaved and cooled before use after amending it with $0.1 \mathrm{gl}^{-1}$ of streptomycin sulfate under a laminar flow. One gram of soil sample was sprinkled on the medium in the petri dish and a suspension of Meloidogyne species of approximately 1000 nematodes was added into the petri dishes as baits (Christina et al., 1999). The plates were then incubated at room temperature and observed daily from the third week up to sixth week under a dissecting microscope. The examination was focused on trapped nematodes, trapping organs and conidia of the nematodes destroying fungi (Wachira et al., 2008).

Taxonomic classification of the nematode destroying fungi was done using the slide culture technique where slides were observed under a microscope while identification of the genus was done using identification keys described by Delgado et al., (2001).After identification of nematode destroying fungi; pure cultures of the three most frequently isolated fungi isolates were made for efficacy experiment. A mycelia block $(5 \mathrm{~mm})$ was inoculated into PDA media in a petri dish and allowed to grow for five days before approximately 50 plant parasitic nematodes were added. The efficacy of the fungi isolates was monitored for a period of 36 weeks. Trapped nematodes were counted for five days, after 3 weeks of incubation. All the data in this study was analyzed through analysis of variance (Kindt \& Coe 2005)

\section{Results}

171 fungi isolates were identified as nematode destroying fungi. They were grouped into three genera and five taxa. The three genera were Arthrobotrys, Monacrosporium and Stylopage. Arthrobotrys was the frequently encountered fungi genera. This generawas represented by, A. oligospora, $A$. dactyloides and $A$. longispora, the genera Monocrosporium was represented by $M$. cionopagium while genera Stylopage was represented by Stylopage grandis. A.oligospora had the highest frequency of occurrence followed by A.dactyloides, $M$. cionopagium, $S$. grandis and the least was A. longispora with. occurrence frequencies of 46.20,45.61,5.85,1.17 and $1.17 \%$ in that decreasing order (Fig I).

The fungi isolates were recovered in all the vegetable production zones. Except for the $A$. dactyloides, all the isolates were not significantly $(\mathrm{P}>0.05)$ affected by the agroecological zones. The highest occurrence of A.dactyloides was 40 being recorded in Kabete while the least was 4 being recorded in Athi-river This species was also recorded in Machakos, Kibwezi and Kinare with records of 19, 10 and 5, respectively, in that decreasing order. Among all the isolates, 
only A.oligospora and A.dactyloides occurred in all agroecological zones. M.cionopagium occurred in all zones except in Kinare while S.grandis was present in both
Kibwezi and Kinare with $A$. longispora being recorded in Kibwezi only (Table 1).

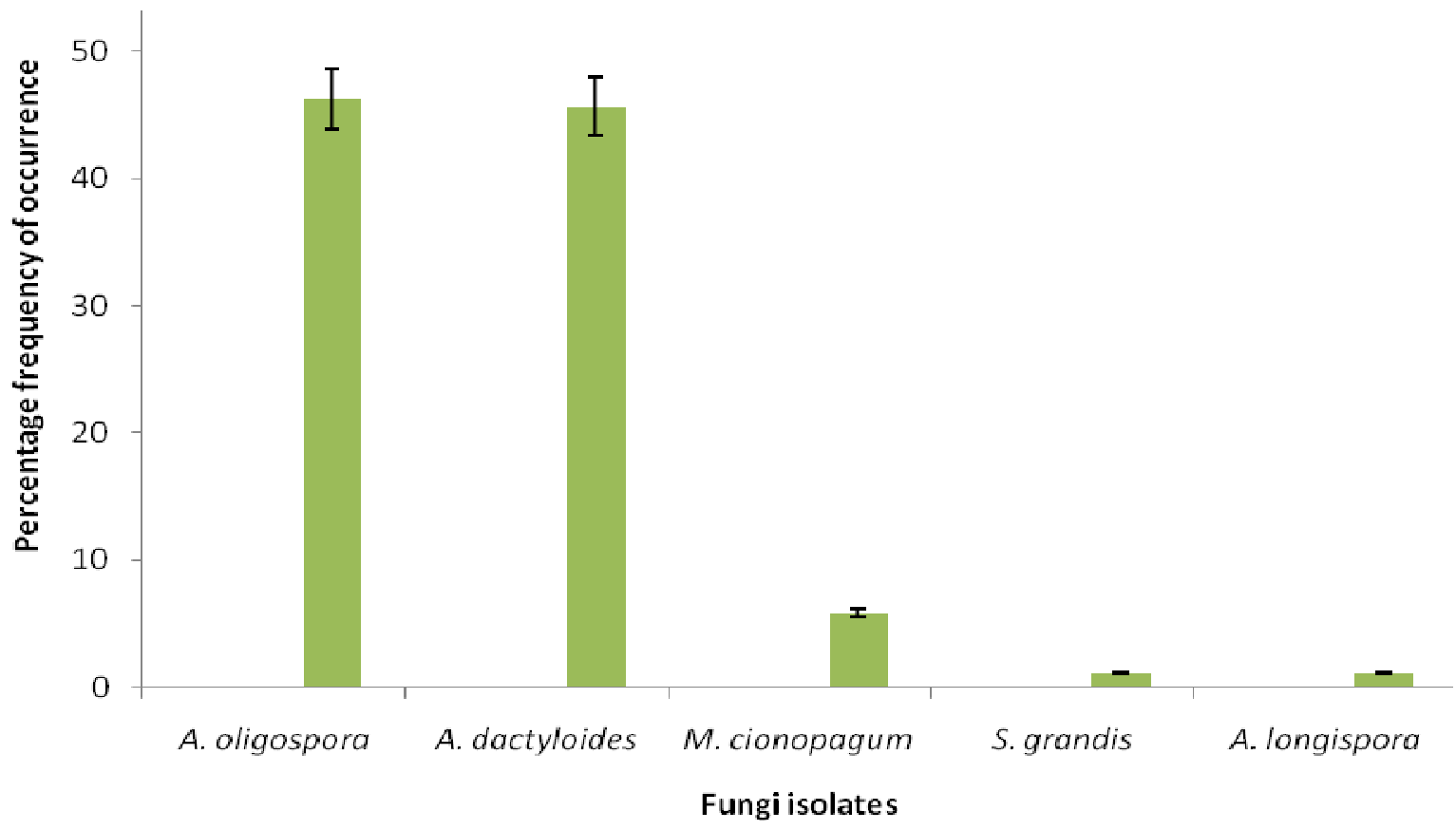

Figure 1. Percentage occurrence of nematode destroying fungi in vegetable production areas in Kenya.

Table 1. Occurrence of nematode destroying fungi in major agro-ecological zones in Kenya.

\begin{tabular}{|c|c|c|c|c|c|c|}
\hline Zone & A. dactyloides & A. oligospora & A. longispora & M. cionopagium & S. grandis & Total \\
\hline Kabete & 20 & 17 & 0 & 1 & 0 & 58 \\
\hline Machakos & 19 & 22 & 0 & 1 & 0 & 42 \\
\hline Kinare & 5 & 7 & 0 & 0 & 1 & 13 \\
\hline Kibwezi & 10 & 20 & 2 & 5 & 1 & 38 \\
\hline Athi-river & 4 & 13 & 0 & 3 & 0 & 20 \\
\hline P.value & 0.002 & 0.395 & 0.062 & 0.165 & 0.062 & \\
\hline
\end{tabular}

The highest number of nematode destroying fungi was recorded in Kabete (Table 1), followed by Machakos, Kiwezi, Athi-river and finally Kinare with total mean abundance of 11.6, 7.6, 7.4, 4.0, and 2.6 in that decreasing order (Table 2). Kibwezi recorded the highest diversity index with a mean of 0.930 , then Machakos with 0.637 while Kabete recorded the least diversity index mean of 0.411. Mean richness and abundance varied between the vegetable production zones. The highest mean species richness was recorded in Kibwezi while the least was recorded at Athi-river. All the agro ecological zones differed significantly $\left(\mathrm{P}=9.587 \times 10^{-4}\right)$ in terms of species abundance. Kabete had the highest species abundance with a mean of 11.6 and least was Kinare with a species mean abundance of 2.6 (Table 2)

Table 2. Mean shannon, species richness and abundance of nematode destroying fungi in different vegetable growing areas in Kenya.

\begin{tabular}{lllll}
\hline Zone & N & Mean Shannon & Mean richness & Mean abundance \\
\hline Kibwezi & 5 & 0.930 & 3.4 & 7.6 \\
Machakos & 5 & 0.637 & 2.2 & 7.4 \\
Athi-river & 5 & 0.483 & 1.6 & 4.0 \\
Kinare & 5 & 0.482 & 1.8 & 2.6 \\
Kabete & 5 & 0.411 & 2.2 & 11.6 \\
P value & & & & $9.587 \times 10^{-4}$ \\
\hline
\end{tabular}

Detection of nematode destroying fungi increased with increase in number of the soil samples taken. It was evident that all possible isolates of nematode destroying fungi were recorded in this study from the samples collected. Collecting and processing additional samples would not significantly increase the number of isolates (Fig 2).

There was a significant $(\mathrm{P}=0.003)$ difference on efficacy between the three most frequent nematode destroying fungi 
species. Arthrobotryrs oligospora was the most efficient nematode destroying fungi with a mean of 7.3 , followed by
Monacrosporium and the least was Stylopage with mean records of 5.9 and 5.1 respectively.

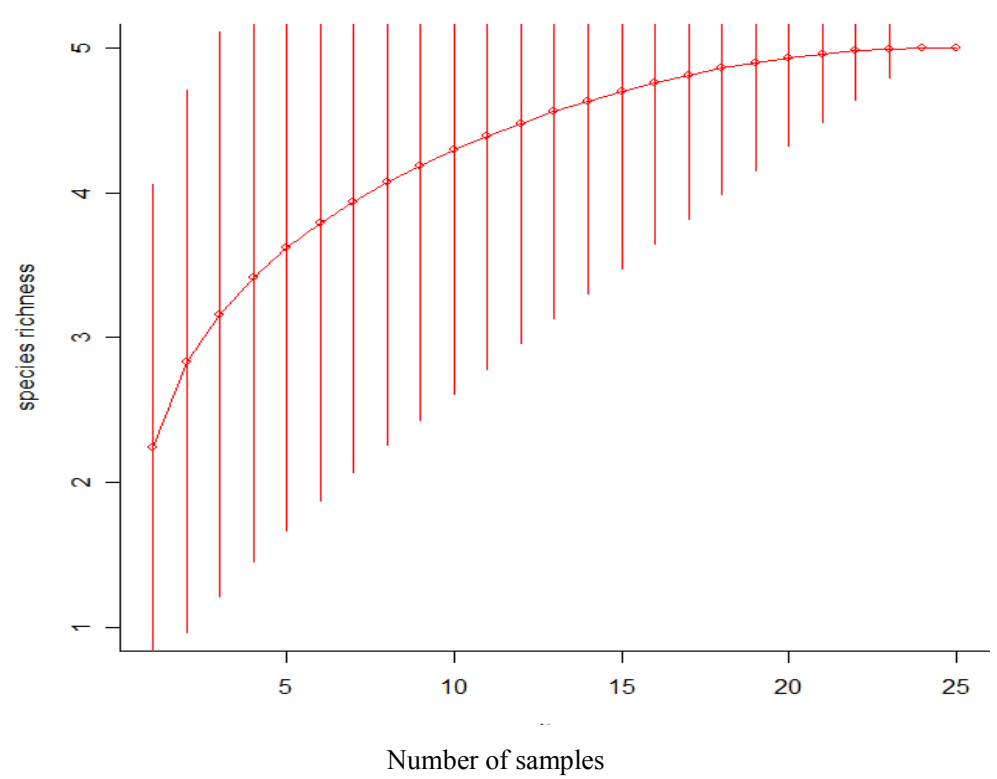

Figure 2. A total species cumulative curve for nematode destroying fungi in the vegetable production zones in Kenya.

\section{Discussion}

Nematode destroying fungi were isolated from all the targeted vegetable production zones. They occurred in different frequencies and diversity. The study has demonstrated the diverse occurrence of nematode destroying fungi in nature and especially in vegetable production zones. These findings agree with previous reports on nematode destroying fungi that they are widespread in all habitat but with different densities and diversities (Birgit et al., 2002, Wachira et al., 2008).

Arthrobotrys oligospora was the most abundant species of nematode destroying fungi in the study area. Other studies on nematode destroying fungi have made the same observation. It has never been clear why this is the most frequently encountered fungi. Wachira et al., (2008) had suggested that farming practices like weeding could be the cause of this high occurrence. It has also been suggested that it is due to its ability to exist both as a saprophyte and a plant parasitic nematode feeder (Sobita and Anamika, 2011). Due to this high occurrence, this fungus is attracting a lot of other interesting studies (Niu and Zhang, 2011).

It was expected that the highest number of fungi would be isolated from areas with low temperature (Kinare). However this was not the case. Kinare had the least number of fungi. This was attributed to the high use of chemical fertilizers and pesticides since all the vegetables were all aimed for market. In a study on long-term effects of manures and fertilizers on soil productivity and quality, it was reported that fertilized soils had lower contents of organic matter and numbers of microfauna than manured soils (Edmeades, 2003). The highest number of nematode destroying fungi was recovered from Kabete. Soils in this area had been collected from the University of Nairobi farm where animal manure is frequently applied. This may explain the high number of nematode destroying fungi since they have been associated with increase of beneficial microorganisms in the soil (Wachira and Okoth, 2009). From this study, there was high fungal population in areas where manure was applied and low fungal population being recorded in areas where chemical fertilizer was applied.

Temperature is an important factor regulating microbial activity and shaping the soil microbial community. It determines moisture levels in the soil which is key to fungal germination and growth. High temperatures lead to low soil moistures which is attributed to low fungal spore germination. A study by Haugen and Smith (1992) reported that at high temperatures there is low germination of fungi spores leading to low fungi populations and while in low temperatures there is high fungal germination leading to high fungal population. This was reported in reverse in our study. Although Machakos and Kibwezi had high temperatures, high population of nematode destroying fungi was reported. This could be attributed to irrigation activities which ensured moist conditions throughout the growth season. This soil moisture, coupled with high temperature enhanced the fungal germination since fungal spore germinates better in moist and warm conditions.

The efficacy test showed that genus Arthrobotrys was the most effective in trapping plant parasitic nematodes. Previous studies on fungi belonging to these genera have consistently showed that it was able to trap $90 \%$ of all the nematodes in petri dish and in liquid culture in 16-40 hours (Rajeswari and Sivakumar, 1999).Therefore, due to its' high occurrence, this fungi can be developed for the management of plant parasitic nematode and its potential should be investigated. The investigation should concentrate on suitable carriers for the fungi and also mode of application. This would reduce over 
reliance on chemical nematicides and also develop a self regulation system in the soil that controls the soil born pests.

\section{Conclusion}

Additional evidence has been provided from this study that nematode destroying fungi are naturally occurring in agricultural habitats. It is also evident that agricultural activities targeting high crop production, like application of chemical fertilizers and pesticides are directly affecting the soil biodiversity. The results of this study can be used for further research to establish the potential of nematode destroying fungi in regulation of plant parasitic nematodes.

\section{Acknowledgement}

The University of Nairobi is acknowledged for providing laboratory equipment and space. We also wish to thank the small scale farmers in the five different vegetable production zones for their cooperation during this study and for providing free access into their farms.

\section{References}

[1] Bridge, J. 1996.Nematode management in sustainable and subsistence agriculture. Plant Parasitic Nematodes in Temperate48 F. JAITEH et al. Agriculture. CABI International WallingfordUK. pp. 203-209.

[2] Christina, P., Stefan, O and J.Hans. 1999. Growth of Arthrobotryssuperba from a birch woodresource base into soil determined by radioactive tracing. Thorvaldsensvej 40, DK1871.

[3] Delgado, A. E., Pinero, A. J and L., M.Urolaneta.2001. Invitro preparatory activity of nematophagous fungi from Costa Rica with potential use for controlling sheep and goat parasitic.

[4] Dobson, H.M., Matthews, G.A., Olembo, S., Baleguel, P and T., L.Wiles.2004. Application challenges for small-scale African farmers: a training initiative in Cameroon. International Advances in Pesticide Application. Aspects of Applied Biology 71:385-392.

[5] Edmeades, D. C.2003.The long-term effects of manures and fertilizers on soil productivity and quality: a review Nutrient Cycling in Agroecosystems66: 165-180.

[6] Elshafie AE, Al-Mueini R, Al- Bahry, Akindi A, Mohmoud I, Al- Rawahi S. 2006. Diversity and trapping efficiency of nematophagous fungi from Oman. Phytopathology Mediterrenian. 45: 266 - 270

[7] Farrell .F.C., Jaffee.B.A and D.,R. Strong.2006.The nematode trapping fungus Arthrobotrysoligospora in soil of the Bodega marine reserve: distribution and dependence on nematodeparasitized moth larvae. Soil Biology and Biochemistry 38:1422-1429.

[8] Haugen, L. M and S., E. Smith.1992.The effect of high temperature and fallow period on infection of mung bean and cashew roots by the vesicular-arbuscular mycorrhizal fungus Glomus:Plant and Soil 145: $71-80$.
[9] Hayward, A.C.1991.Biology and epidemiology of bacterial wilt caused by Pseudomonas solanacearum. Annual Review Phytopathology 29: 65-87.

[10] Jaffee, B.A., Srong, D.R and A., E.Milton.1996.Nematode trapping fungi of natural shrubland: Tests for food chain involvement. Mycologia, 88:554-564.

[11] Jansson, H.B., Persson, C and R. Odeslus.2000. Growth and capture activities of nematode destroying fungi in soil visualized by low temperature scanning electron microscopy. Mycologia 92:10 - 15 .

[12] Kaskavalci, G. 2007.Effect of soil solarization and organic amendment treatments for controlling Meloidogyne incognita in tomato cultivars in Western Anatolia. Turkish Agricultural Forum31: 159-167.

[13] Keren-Zur, M., Antonov, J., Bercovitz, A.,Feldman, A., Keram, G., Morov and N. Rebhum. 2000. Baccillusfirmusformulation for the safe control of root knot nematodes. The BCPC Conference.Pests and Disease, Brighton, UK.pp.307-311.

[14] Kindt, R and R. Coe, 2005. Tree diversity analysis. A manual and software for common statistical methods for ecological and biodiversity studies. Nairobi: World Agro-forestry Center (ICRAF).

[15] Masoomeh, S.G., Mehdi, R.A., Sharokh, R.B., Ali, E.R.Z and E. Majid.2004. Screening of soil and sheep faecal samples for predacious fungi:Isolation and characterization of the nematode - trapping fungus Arthrobotrys oligospora. Iranian Biomedical. 8: $135-142$.

[16] Nchore, S.B., Waceke, J.W and KariukiG., M.2010. Incidence and prevalence of root-knot nematode Meloidogyne species in selected indigenous leafy vegetables in Kisii and Trans-Mara Counties of Kenya. In: Transforming Agriculture for improved livelihoods through Agricultural Product Value Chains. 12th KARI Biennial Scientific Conference,November 8-12, 2010,Nairobi,Kenya.KARI,pp. 675-681.

[17] Nordbring-Hertz, B., H.B. Jansson and A. Tunlid .2002.Nematophagous Fungi: Encyclopedia of Life Sciences. Macmillan Publishers Ltd., London.

[18] Pinkerton JN, Ivors KL, Miller ML and Moore LW, 2000.Effect of solarization and cover crops on populations of selected soil borne plant pathogens in western Oregon. Plant Diseases 84: 952-960.

[19] Rajeswari.S and C., V.Sivakumar.1999.Occurrence of nematophagous fungi (Hyphhomycetes and their predacious ability in Tamil Nadu).Journal of Biological control 13:107110 .

[20] Rodrigues, M.L.A., Castro, A.A., Oliveira, C.R., Anjos, D.H.S., Bittencourt, V.R.E.P and J., V.Aranjo.2001. Trapping capabilities of Arthrobotryssp and Monacrosporium thaumasium on Cyathostoma, larvae. Veterinary Parasitology10: 51 - 54 .

[21] Sanyal, P.K.2000. Screening for Indian isolates of predacious fungi for use in biological control against nematode parasites of ruminants. Veterinary Research Communications 24: 5562.

[22] Sobita Simon and Anamika.2011. Management of Root Knot Disease in Rice Caused by Meloidogyne graminicola through Nematophagous Fungi. Journal of Agricultural Science 3: 122 $-127$. 
[23] Wachira, P.M and Okoth, S.A. 2009. Use of nematode destroying fungi as indicators of land disturbance in TaitaTaveta, Kenya Tropical and Subtropical Agroecosystems, 11: $313-321$
[24] Wachira, P.M., Kimenju, J.W., Okoth, S., Mibey, R.K and J. Mungatu.2008. Effect of land use on occurrence and diversity of nematode destroying fungi in TaitaTaveta, Kenya. Asian journey of Plant Sciences 7: 447-453. 